\begin{tabular}{|c|l|}
\hline Title & $\begin{array}{l}\text { Distribution of glycerol dialkyl glycerol tetraethers, al kenones and poly unsaturated fatty acids in suspended particul ate } \\
\text { organic matter in the East China Sea }\end{array}$ \\
\hline Author(s) & Nakanishi, Takahiro; Y amamoto, Masanobu; Irino, Tomohisa; Tada, Ryuji \\
\hline Citation & $\begin{array}{l}\text { Journal of Oceanography, 68(6), 959-970 } \\
\text { https:/doi.org/10.1007/s10872-012-0146-4 }\end{array}$ \\
\hline Issue Date & 2012-12 \\
\hline Doc URL & http://hdl.handle.net/2115/54010 \\
\hline Type & article (author version) \\
\hline File Information & Jo068_6_959-970.pdf \\
\hline
\end{tabular}

Instructions for use 


\section{Distribution of glycerol dialkyl glycerol tetraethers, alkenones and polyunsaturated fatty acids in suspended particulate organic matter in the East China Sea}

Takahiro Nakanishi $^{\mathrm{a},+}$, Masanobu Yamamoto ${ }^{\mathrm{a}, *}$, Tomohisa Irino ${ }^{\mathrm{a}}$, Ryuji Tada ${ }^{\mathrm{b}}$

${ }^{a}$ Faculty of Environmental Earth Science, Hokkaido University, Sapporo, Japan

${ }^{\mathrm{b}}$ Department of Earth and Planetary Science, Graduate School of Science, The University of Tokyo, Tokyo, Japan

${ }^{+}$Present Address: NITTOC Construction Co., Ltd., Tokyo, Japan

*Corresponding author. Tel.: +81-11-706-2379; fax: +81-11-706-4867.

E mail address: myama@ees.hokudai.ac.jp) (M. Yamamoto)

Key words: GDGT, TEX 86 , alkenone, $\mathrm{U}_{37}^{\mathrm{K}}$, POM, the East China Sea

\section{ABSTRACT}

We investigated the spatial distribution of glycerol dialkyl glycerol tetraethers (GDGTs), alkenones, and polyunsaturated fatty acids in particulate organic matter collected at four sites along a depth transect from the continental shelf to the Okinawa Trough in the East China Sea during the spring bloom in 2008. The maximum alkenone concentration appeared in the top $25 \mathrm{~m}$ at all sites and the $\mathrm{U}_{37}^{\mathrm{K}}$ values were consistent with in-situ water temperatures in the depth interval, suggesting that the alkenones were produced mainly in surface water. At the slope and shelf sites, GDGTs in the water column showed a concentration maximum at 74-99 m depth, and the $\mathrm{TEX}_{86}^{\mathrm{H}}$ agreed with in-situ water temperatures, suggesting the in-situ production of GDGTs in the depth interval. The low-salinity surface water above $20 \mathrm{~m}$ depth was characterized by low GDGT concentrations and low $\mathrm{TEX}_{86}^{\mathrm{L}}$-based temperatures, 
suggesting either the production of GDGTs in winter season or the lateral advection of GDGTs by an eastward current. At the slope and Okinawa Trough sites, $\mathrm{TEX}_{86}$-based temperatures were nearly constant in the water column deeper than $300 \mathrm{~m}$ and corresponded to temperatures at the surface and near-surface waters rather than in situ temperatures. This observation is consistent with a hypothesis that Thaumarchaeota cells produced in surface waters are delivered to deeper water and also indicates that the residence time of suspended GDGTs in the deep water column is large enough to mix the GDGTs produced in different seasons.

\section{Introduction}

Glycerol dialkyl glycerol tetraethers (GDGTs) are ubiquitous in marine water and sediments, and are thought to be derived mainly from marine Crenarchaeota Group I (Sinninghe Damsté et al., 2002b), and marine Crenarchaeota Group I was recently classified into a newly-defined archaeal phylum Thaumarchaeota (Brochier-Armanet et al., 2008; Spang et al., 2010). The GDGTs biosynthesized by this group include GDGT-0 (caldarchaeol)-GDGT-3, containing zero to three cyclopentane moieties, and crenarchaeol, which has a cyclohexane moiety in addition to four cyclopentane moieties (Schouten et al., 2000; Sinninghe Damsté et al., 2002b).

The ecology and physiology of Thaumarchaeota in marine environments are not fully understood. They live throughout the water column (e.g., Murray et al., 1999; Karner et al., 2001; Herndl et al., 2005; Baltar et al., 2007; Coolen et al., 2007; Agogué et al., 2008; Beman et al., 2008; Verala et al., 2008). They occur in highest abundances in the upper $100 \mathrm{~m}$, but are also present in waters as deep as $5000 \mathrm{~m}$ (Karner et al., 2001; Herndl et al., 2005). Thaumarchaeota in marine environments were recognized to be both heterotrophs (e.g., Ouverney and Furman, 2000; Agogué et al., 2008; Zhang et al., 2009) and chemoautotrophic nitrifiers (e.g., Könnek et al., 2005; Hallam et al., 2006; Wuchter et al., 2006; Coolen et al., 
2007; Beman et al., 2008; Park et al., 2010; Blainey et al., 2011; Pitcher et al., 2011).

Because isoprenoid GDGTs are specific to Archaea, and creanarchaeol, a major isoprenoid GDGT, is specific to Thaumarchaeota in particular, they are potentially used to understand the temporal and spatial distribution of Achaea and Thaumarchaeota, but little is known about the abundance of GDGTs in the water column. Sinninghe Damste et al. (2002a) described maxima of crenarchaeol concentrations at $70 \mathrm{~m}$ and $500 \mathrm{~m}$ in the Arabian Sea. Wuchter et al. (2005) reported a high concentration of GDGTs in particulate organic matter (POM) in the deep-water column below $100 \mathrm{~m}$. The abundance of GDGTs also varies seasonally. A high abundance was reported for winter in the North Sea (Wuchter et al., 2005; Herfort et al., 2006), suggesting that Thaumarchaeota thrive in winter because they do not need to compete with phytoplankton for $\mathrm{NH}_{3}$. This hypothesis was recently supported by the observation that the abundance of intact GDGTs and Thaumarchaeota 16S rRNA genes and amoA genes showed a seasonal cycle with maxima in winter in the North Sea (Pitcher et al., 2011). Turich et al. (2007) reported the variability in GDGT composition in the water column in different oceanographic settings.

Schouten et al. (2002) proposed a new palaeotemperature index, TetraEther index of tetraethers consisting of 86 carbon atoms $\left(\mathrm{TEX}_{86}\right)$, based on the distribution of GDGTs by way of an empirical correlation between $\mathrm{TEX}_{86}$ values in marine core top sediments and sea surface temperatures (SSTs). Investigation of such a correlation has since been developed using larger data sets (Kim et al., 2008; 2010). The application of $\mathrm{TEX}_{86}$ is increasing in palaeoceanographic studies (e.g. Huguet et al., 2006b). Because GDGTs record the water temperature when and where they were produced, the temperatures indicated by the GDGTs in POM provide a key for understanding the season and depth of GDGT production.

In this study, we investigated the spatial distribution of GDGTs, alkenones and polyunsaturated fatty acids in POM collected during the spring bloom in 2008 from the East China Sea (ECS) to better understand the production and fate of GDGTs in the water column. 
Alkenones are specific to some haptophytes algae, and the unsaturation index of alkenones $\mathrm{U}_{37}^{\mathrm{K}}$ is a paleotemperature index which records the temperature when and where the alkenones were produced (Brassell et al., 1986; Prahl and Wakeham, 1987). Polyunsaturated fatty acids are a specific biomarker of algae, and can be used for detecting phytoplankton production (Volkman et al., 1989). The results of alkenones and polyunsaturated fatty acids were discussed together with GDGTs. Biomarkers in POM from the ESC were previously investigated (e.g., sterols by Sicre et al., 1994), but this is the first report of GDGTs and alkenones in POM from the ECS.

\section{Materials and methods}

\subsection{Study area}

The ECS is a marginal sea bounded by the Asian continent on the west, Taiwan Island to the southwest, the Ryukyu Islands to the southeast, and Kyushu and the Korean Peninsula to the northeast and north, respectively (Fig. 1). The continental shelf, which is shallower than $200 \mathrm{~m}$, occupies $>70 \%$ of the entire ECS. The Okinawa Trough, with a maximum water depth of $>2000 \mathrm{~m}$, lies in the south-eastern part of the ECS along the Ryukyu Arc. The Kuroshio enters the ECS through the strait between Taiwan and Yonakuni-jima (Yonakuni Island), flows north-eastward along the shelf slope, and exits to the Pacific Ocean through the Tokara Strait (Ichikawa and Beardsley, 2002).

The study sites were located at the contact zone between the warm and saline Kuroshio water and the cold and less saline Changjiang diluted water (CDW)/Yellow Sea central cold water mass (Fig. 1; Kondo, 1985; Ichikawa and Beardsley, 2002). Temperature and salinity are nearly constant from the surface to $100 \mathrm{~m}$ in winter. In summer, less saline water originating from the CDW mixes with the sea surface water and a thermocline develops, mainly as a result of the radiative heating by insolation. The SST is maximal in August and

minimal in February (Japan Oceanographic Data Center; available at 
http://www.jodc.go.jp/index.html). Sea surface salinity reaches its maximum value in February and minimum value in July, when the maximum discharge from the Changjiang (Yangtze River) occurs (Japan Oceanographic Data Center; available at http://www.jodc.go.jp/index.html).

In the ECS, phytoplankton bloom occurs in spring (e.g., Takagi et al., 1993). In the spring bloom of 1996, diatoms were abundant on the shelf, whereas prochlorophytes, chrysophytes, haptophytes, and chlorophytes were abundant in Okinawa Trough waters (Furuya et al., 2003). A sediment trap study conducted in 1993 and 1994 showed that E. huxleyi, an alkenone producer, dominated in haptophytes, and its sinking flux was maximal in spring (Tanaka, 2003). Surface chlorophyll-a concentration extracted from daily $9 \mathrm{~km}$ satellite data of NASA Sea WiFS standard map (http://oceancolor.gsfc.nasa.gov/) image in the study area showed that phytoplankton occurred repeatedly from February to May 2008.

\subsection{Samples}

Seawater samples were collected at different depths at four sites using Niskin bottles during the R/V Tansei-maru KT08-10 cruise in May 2008 (Fig. 1; Table 1). Suspended POM was collected by filtering 101 of seawater through a precombusted GF/F glass fibre filter $(0.7$ $\mu \mathrm{m})$. The samples were kept frozen at $-20^{\circ} \mathrm{C}$ until analysis. Water temperature and salinity were measured using a conductivity temperature sensor. A high concentration of chlorophyll $a(>1 \mu \mathrm{g} / \mathrm{l})$ in the surface water was observed along the PN line $\left(29^{\circ} \mathrm{N}, 126^{\circ} \mathrm{E}-27.5^{\circ} \mathrm{N}\right.$, $128.5^{\circ} \mathrm{E}$ ), south of the study area during the $\mathrm{R} / \mathrm{V}$ Chofu-maru cruise of the Japan $\begin{array}{llll}\text { Meteorological } & \text { Agency } & \text { in } & \text { May }\end{array}$ (http://www.data.kishou.go.jp/kaiyou/db/vessel_obs/nagasaki/index.php), indicating that the phytoplankton spring bloom had occurred in the eastern ECS.

A multiple core (PL-1; $30 \mathrm{~cm}$ long) was collected from a water depth of $758 \mathrm{~m}$ on the northern slope of the ECS at $31^{\circ} 38.35^{\prime} \mathrm{N}, 128^{\circ} 56.64^{\prime} \mathrm{E}$ during the R/V Kaiyo KY07-04 cruise 
(Figure 1). The sediment of core PL-1 consists of brown (top $3 \mathrm{~cm}$ ) to olive-grey clay. The top $1 \mathrm{~cm}$ of sediment was used as a surface sediment sample for this study.

\subsection{Analytical methods}

Lipids were extracted three times from a freeze-dried sample using a DIONEX Accelerated Solvent Extractor ASE-200 at $100^{\circ} \mathrm{C}$ and 1000 psi for 10 min with $11 \mathrm{ml}$ of $\mathrm{CH}_{2} \mathrm{Cl}_{2} / \mathrm{CH}_{3} \mathrm{OH}$ (6:4) and then concentrated. The extract was separated into four fractions using column chromatography $\left(\mathrm{SiO}_{2}\right.$ with $5 \%$ distilled water; i.d., $5.5 \mathrm{~mm}$; length, $\left.45 \mathrm{~mm}\right)$ : F1 (hydrocarbons), 3ml hexane; F2 (aromatic hydrocarbons), $3 \mathrm{ml}$ hexane-toluene (3:1); F3 (ketones), $4 \mathrm{ml}$ toluene; F4 (polar compounds), $3 \mathrm{ml}$ toluene- $\mathrm{CH}_{3} \mathrm{OH}$ (3:1). $n-\mathrm{C}_{36} \mathrm{H}_{74}$ was added as an internal standard to F3.

An aliquot of $\mathrm{F} 4$ was trans-esterified with $1 \mathrm{ml} 5 \% \mathrm{HCl} / \mathrm{CH}_{3} \mathrm{OH}$ at $60{ }^{\circ} \mathrm{C}$ for $12 \mathrm{~h}$ under $\mathrm{N}_{2}$. The methylated lipids were supplemented with $2 \mathrm{ml}$ distilled water and extracted three times with toluene. The extract was back washed three times with distilled water, passed through a short bed of $\mathrm{Na}_{2} \mathrm{SO}_{4}$, and separated into two fractions with $\mathrm{SiO}_{2}$ column chromatography: F4-1 (acids), $4 \mathrm{ml}$ toluene; F4-2 (alcohols), $3 \mathrm{ml}$ toluene- $\mathrm{CH}_{3} \mathrm{OH}$ (3:1). $n-\mathrm{C}_{24} \mathrm{D}_{50}$ was added as an internal standard to F4-1.

Gas chromatography (GC) of F3 (alkenones) and F4-1 (fatty acids, FAs) was conducted using a Hewlett Packard 5890 series II gas chromatograph with on-column injection and electronic pressure control systems, and a flame ionization detector. Samples were dissolved in hexane. He was the carrier gas at $30 \mathrm{~cm} / \mathrm{s}$. A Chrompack CP-Sil5CB column was used (60 $\mathrm{m} x \quad 0.25 \mathrm{~mm}$ i.d.; film thickness, $0.25 \mu \mathrm{m})$. The oven temperature was programmed to rise from 70 to $290^{\circ} \mathrm{C}$ at $20^{\circ} \mathrm{C} / \mathrm{min}$, from 290 to $310^{\circ} \mathrm{C}$ (held $30 \mathrm{~min}$ ) at $0.5^{\circ} \mathrm{C} / \mathrm{min}$ for analysis of F3; for F4-1 the program was: 70 to $130{ }^{\circ} \mathrm{C}$ at $20^{\circ} \mathrm{C} / \mathrm{min}$, then to $310{ }^{\circ} \mathrm{C}$ (held $>30 \mathrm{~min}$ ) at 4 ${ }^{\circ} \mathrm{C} / \mathrm{min}$. The standard deviation of five duplicate analyses averaged $7.5 \%$ of the concentration for each compound. 
GC-mass spectrometry of F3 and F4-1 was conducted using a Hewlett Packard 5973 GC-mass selective detector with on-column injection and electronic pressure control systems, and a quadrupole mass spectrometer. The GC column and oven temperature and carrier pressure programs were as above. The mass spectrometer was run in full scan mode $(\mathrm{m} / \mathrm{z}$ 50-650). Electron ionization spectra were obtained at $70 \mathrm{eV}$. Compound identification was achieved by comparing mass spectra and retention times with those of standards and published data.

The alkenone unsaturation index $\mathrm{U}_{37}^{\mathrm{K}}$ was calculated from the concentrations of di- and tri-unsaturated $\mathrm{C}_{37}$ alken-2-ones $\left(\left[\mathrm{C}_{37: 2} \mathrm{MK}\right]\right.$ and $\left[\mathrm{C}_{37: 3} \mathrm{MK}\right]$, respectively) using the following expression (Prahl et al., 1988):

$$
\mathrm{U}_{37}^{\mathrm{K}^{\prime}}=\left[\mathrm{C}_{37: 2} \mathrm{MK}\right] /\left(\left[\mathrm{C}_{37: 2} \mathrm{MK}\right]+\left[\mathrm{C}_{37: 3} \mathrm{MK}\right]\right) .
$$

Temperature was calculated according to the equation

$$
\mathrm{U}_{37}^{\mathrm{K}^{\prime}}=0.034 \mathrm{~T}+0.039
$$

where $\mathrm{T}$ is temperature $\left[{ }^{\circ} \mathrm{C}\right]$ based on experimental results for cultured strain $55 \mathrm{a}$ of Emiliania huxleyi (Prahl et al., 1988); analytical accuracy (standard deviation in a replicate analysis) was $0.24{ }^{\circ} \mathrm{C}$ in our laboratory.

An aliquot of F4 was dissolved in hexane-2-propanol (99:1) and filtered. GDGTs were analyzed using high performance liquid chromatography-MS with an Agilent 1100 HPLC system connected to a Bruker Daltonics micrOTOF-HS time-of-flight mass spectrometer. Separation was conducted using a Prevail Cyano column $(2.1$ x $150 \mathrm{~mm}, 3 \mu \mathrm{m}$; Alltech) maintained at $30{ }^{\circ} \mathrm{C}$ following the method of Hopmans et al. (2000) and Schouten et al. (2007). Conditions were: flow rate $0.2 \mathrm{ml} / \mathrm{min}$, isocratic with $99 \%$ hexane and $1 \%$ 2-propanol for the 
first 5 min followed by a linear gradient to $1.8 \%$ 2-propanol over $45 \mathrm{~min}$. Detection was achieved using atmospheric pressure, positive ion chemical ionization-MS. The spectrometer was run in full scan mode $(\mathrm{m} / \mathrm{z}, 500-1500)$. Compounds were identified by comparing mass spectra and retention times with those of GDGT standards (obtained from the main phospholipids of Thermoplasma acidophilum via acid hydrolysis) and those in the literature (Hopmans et al., 2000). Quantification was achieved by integrating the summed peak areas in the protonated molecular ion $(\mathrm{M}+\mathrm{H})^{+}$and the isotopic ion $(\mathrm{M}+\mathrm{H}+1)^{+}$chromatograms and comparing these with the peak area of an internal standard $\left(\mathrm{C}_{46}\right.$ GDGT; Patwardhan and Thompson, 1999) in the $(\mathrm{M}+\mathrm{H})^{+}$chromatogram, according to the method of Huguet et al. (2006a). The correction value of ionization efficiency between GDGTs and the internal standard was obtained by comparing the peak areas of T. acidophilum-derived mixed GDGTs and $\mathrm{C}_{46}$ GDGT in known amounts. The standard deviation of a replicate analysis was $3.0 \%$ of the concentration for each compound. $\mathrm{TEX}_{86}$ and $\mathrm{TEX}_{86}^{\mathrm{H}}$ (applicable to warm water) were calculated from the concentrations of GDGT-1, GDGT-2, GDGT-3 and a regioisomer of crenarchaeol using the following expressions (Schouten et al., 2002; Kim et al., 2010):

$$
\begin{aligned}
\mathrm{TEX}_{86}= & ([\text { GDGT-2]+[GDGT-3]+[Crenarchaeol regioisomer }]) / \\
& ([\text { GDGT-1]+[GDGT-2]+[GDGT-3]+[Crenarchaeol regioisomer }]) \\
\mathrm{TEX}_{86}^{\mathrm{H}}= & \log \left(\mathrm{TEX}_{86}\right)
\end{aligned}
$$

$\mathrm{TEX}_{86}^{\mathrm{L}}$, applicable in cooler water, was calculated from the concentrations of GDGT-1, GDGT-2 and GDGT-3 using the following expression (Kim et al., 2010):

$$
\mathrm{TEX}_{86}^{\mathrm{L}}=\log \{[\text { GDGT-2] / ([GDGT-1]+[GDGT-2]+[GDGT-3]) }\}
$$

Temperature was calculated according to the following equation based on a global core top 
calibration (Kim et al., 2010):

$$
\begin{aligned}
& \mathrm{T}=68.4 \mathrm{TEX}_{86}^{\mathrm{H}}+38.6\left(\text { when } \mathrm{T}>15^{\circ} \mathrm{C}\right) \\
& \mathrm{T}=67.5 \mathrm{TEX}_{86}^{\mathrm{L}}+46.9\left(\text { when } \mathrm{T}<15^{\circ} \mathrm{C}\right)
\end{aligned}
$$

where $\mathrm{T}=$ temperature $\left[{ }^{\circ} \mathrm{C}\right]$; analytical accuracy was $0.45^{\circ} \mathrm{C}$ in our laboratory.

\section{Results}

\subsection{Water temperatures and salinity}

Measured SSTs were $19.3^{\circ} \mathrm{C}$ at a continental shelf site (St. 11), $22.4^{\circ} \mathrm{C}$ at a continental slope site (St. 12 ), and $21.0^{\circ} \mathrm{C}$ and $20.5^{\circ} \mathrm{C}$ at Okinawa Trough sites (St. 8 and St. 1, respectively). The SSTs were highest at the continental slope site, because the axis of the Kuroshio branch current west of Kyushu (KBCWK) lies along the western flank of the northern Okinawa Trough (Fig. 1; Ichikawa and Beardsley, 2002) and the KBCWK transports warm water northward. The temperature decreased with increasing depth at each site, implying the development of a seasonal thermocline in May 2008.

Measured sea surface salinities were 33.7 at the continental shelf site (St. 11), 33.7 at the continental slope site (St. 12), and 34.1 and 34.0 at the Okinawa Trough sites (St. 8 and St. 1, respectively). Sea surface salinity tended to be lower at the shelf site (St. 11) and a slope site (St. 12) than at the trough sites (St. 8 and St. 1). The salinity was lowest at the surface at each site. This is because the low-salinity CDW spreads from the estuary of the Chiangjiang eastward as a low-salinity lens and mixes with the high salinity Kuroshio water (Fig. 1; Ichikawa and Beardsley, 2002). The low salinity layers were intercalated in the interval above $200 \mathrm{~m}$ at St. 1, St. 11, and St. 12. The subsurface low-salinity water originates from the Yellow Sea central cold water formed in the Yellow Sea by winter cooling (Fig. 1; Ichikawa and Beardsley, 2002). The salinity maximum was at depths of approximately 150 to $200 \mathrm{~m}$ at 
trough sites St. 1 and St. 8. This maximum represents the core of the Kuroshio Current.

\subsection{Alkenones}

Total alkenone concentrations varied between 0 and $135.7 \mathrm{ng} / \mathrm{l}$ in all POM samples (Table 2) and decreased westward (Fig. 2). They reached a maximum in surface water ( 5-25 m) and decreased with increasing depth at each site (Fig. 2).

The $\mathrm{U}_{37}^{\mathrm{K}}$ value varied differently at each of the sites. At St. 11, $\mathrm{U}_{37}^{\mathrm{K}}$-based temperatures were $17^{\circ} \mathrm{C}$ at $5-10 \mathrm{~m}$ depth, decreased to $14^{\circ} \mathrm{C}$ at $25 \mathrm{~m}$ depth, and increased to $20^{\circ} \mathrm{C}$ at $86 \mathrm{~m}$ depth (Fig. 2). At St. 12, $\mathrm{U}_{37}^{\mathrm{K}^{\prime}}$-based temperatures were $23-24^{\circ} \mathrm{C}$ at $5-20 \mathrm{~m}$ depth, decreased to $17^{\circ} \mathrm{C}$ at $50 \mathrm{~m}$ depth, gradually increased downward to $24^{\circ} \mathrm{C}$ by $199 \mathrm{~m}$ depth, and then decreased $20^{\circ} \mathrm{C}$ by $558 \mathrm{~m}$ depth (Fig. 2). At St. 8, $\mathrm{U}_{37}^{\mathrm{K}}$-based temperatures were $22^{\circ} \mathrm{C}$ at $5-20$ m depth, decreased to $19^{\circ} \mathrm{C}$ by $74 \mathrm{~m}$ depth, and then were nearly constant downward until $198 \mathrm{~m}$ depth (Fig. 2). At St. 1, $\mathrm{U}_{37}^{\mathrm{K}}$-based temperatures were $22^{\circ} \mathrm{C}$ at $5-20 \mathrm{~m}$ depth, decreased to $18^{\circ} \mathrm{C}$ by $99 \mathrm{~m}$ depth, and were then nearly constant downward at $18-21^{\circ} \mathrm{C}$ by $690 \mathrm{~m}$ depth (Fig. 2). The $\mathrm{U}_{37}^{\mathrm{K}}$-based temperatures did not generally agree with in-situ water temperatures, but agreed with in-situ water temperatures at the depth showing the maximum alkenone concentration (25 m at St. 11, $11 \mathrm{~m}$ at St. 12, $20 \mathrm{~m}$ at St. 8 and $5 \mathrm{~m}$ at St. 1; Fig. 2).

\subsection{Polyunsaturated fatty acids}

The major poly-unsaturated fatty acids (PUFAs) in samples were $n$ - $\mathrm{C}_{20: 5}$ and $n$ - $\mathrm{C}_{22: 6}$ ( $n$-20:5 and $n-22: 6$, respectively). The concentration of $n-22: 6$ showed a maximum at 5-20 m depth and decreased with increasing depth. At St. 11, a second maximum occurred near the sediment surface at the shelf site (St. 11). The concentration profile of $n$-20:5 was similar to that of $n-22: 6$ (data not shown).

\subsection{GDGTs}


GDGTs consisted of caldarchaeol [GDGT-0], GDGT-1, GDGT-2, GDGT-3, crenarchaeol and its regioisomer, and branched GDGTs. Creanrachaeol is the major component of the GDGTs and occupies from 48 to $62 \%$ of total GDGT. Caldarchaeol is the second major component and occupies from 26 to $45 \%$ of total GDGT. This compositional pattern is typical of that seen in the GDGTs in the extract of Thaumarchaeota (Wuchter et al., 2004). Total isoprenoid GDGT concentrations (the sum of concentrations of caldarchaeol, GDGT-1, GDGT-2, GDGT-3, and crenarchaeol and its regioisomer) varied between 0.2 and $35.2 \mathrm{ng} / \mathrm{l}$ in all POM samples (Table 2) and decreased eastward (Fig. 3). The highest concentrations (35.2 $\mathrm{ng} / \mathrm{l})$ were at $86 \mathrm{~m}$ at the shelf site (St. 11), $99 \mathrm{~m}$ at the slope site (15.2 ng/l; St. 12), and $50 \mathrm{~m}$ at the trough site $(4.3 \mathrm{ng} / \mathrm{l}$; St. 8). At St. 1, the concentration was highest at $693 \mathrm{~m}(6.2 \mathrm{ng} / \mathrm{l})$, just above the sediment surface.

In all samples, the majority of the GDGTs consisted of isoprenoids. Branched GDGTs were detected in trace amounts $(<2 \%$ of total isoprenoid GDGTs, BIT values [Hopmans et al., $2004]<0.034$; Table 2) in only four samples, i.e. three deeper samples at the shelf site (St. 11) and the shallowest sample at the slope site (St. 12), indicating a low contribution of terrestrial soil organic matter at the study sites. Weijers et al. (2006) noted that samples with high BIT values (> 0.4) may show anomalously high $\mathrm{TEX}_{86}$-derived temperatures. This concern is, however, not relevant for the samples used in this study.TEX ${ }_{86}^{\mathrm{H}}$ was lower at the shelf site (St. 11) than at the other sites. At St. $11, \mathrm{TEX}_{86}^{\mathrm{H}}$-based temperatures were $4-5^{\circ} \mathrm{C}$ at 5-10 m depth, increased to $13^{\circ} \mathrm{C}$ at $25 \mathrm{~m}$ depth, and were nearly constant by $86 \mathrm{~m}$ depth (Fig. 3). At St. 12 , the $\mathrm{TEX}_{86}^{\mathrm{H}}$-based temperature was $13^{\circ} \mathrm{C}$ at $5-10 \mathrm{~m}$ depth, increased to $23^{\circ} \mathrm{C}$ at $20 \mathrm{~m}$ depth, gradually decreased downward to $17^{\circ} \mathrm{C}$ by $149 \mathrm{~m}$ depth, then increased to $22^{\circ} \mathrm{C}$ at $198 \mathrm{~m}$ depth, and then became nearly constant by $558 \mathrm{~m}$ depth (Fig. 3). At St. 8, TEX ${ }_{86}^{\mathrm{H}}$ -based temperatures were $7-10^{\circ} \mathrm{C}$ at $5-10 \mathrm{~m}$ depth, increased to $18^{\circ} \mathrm{C}$ at $50 \mathrm{~m}$ depth, and gradually increased downward to $20^{\circ} \mathrm{C}$ by $198 \mathrm{~m}$ depth (Fig. 3). At St. 1, TEX ${ }_{86}^{\mathrm{H}}$-based temperatures were $13-15^{\circ} \mathrm{C}$ at $5-20 \mathrm{~m}$ depth, decreased to $8^{\circ} \mathrm{C}$ at $74 \mathrm{~m}$ depth, increased to 
$19^{\circ} \mathrm{C}$ at $99 \mathrm{~m}$ depth, decreased again to $15^{\circ} \mathrm{C}$ at $149 \mathrm{~m}$ depth, and gradually increased downward to $22^{\circ} \mathrm{C}$ by $690 \mathrm{~m}$ depth (Fig. 3). The $\mathrm{TEX}_{86}^{\mathrm{H}}$-based temperatures generally did not agree with measured water temperatures (Fig. 3). $\mathrm{TEX}_{86}^{\mathrm{H}}$-based temperatures were lower than measured water temperatures in surface water, and higher than measured water temperatures in the deep water. Exceptionally, they agreed with measured water temperature at $74-86 \mathrm{~m}$ depth at St. 11 and at 5-149 m depth at St. 12 (Fig. 3).

The variation in $\mathrm{TEX}_{86}^{\mathrm{L}}$-based temperature was somehow consistent with the variations in $\mathrm{TEX}_{86}^{\mathrm{H}}$-based temperature at St. 11 and St. 12, but the difference was significant and larger than the standard errors of the estimate for $\mathrm{TEX}_{86}^{\mathrm{L}}$ and $\mathrm{TEX}_{86}^{\mathrm{H}}$ calibrations $\left(4.0^{\circ} \mathrm{C}\right.$ and $2.5^{\circ} \mathrm{C}$, respectively) for surface water $(<11 \mathrm{~m})$; $\mathrm{TEX}_{86}^{\mathrm{L}}$-based temperatures were about $8^{\circ} \mathrm{C}$ higher than TEX $_{86}^{\mathrm{H}}$-based temperatures (Fig. 3). At St. 8 and St. 1, the difference is within calibration standard errors in most samples (Fig. 3), aside from the sample at $74 \mathrm{~m}$ at St. 1 that shows about $8^{\circ} \mathrm{C}$ difference, which is larger than calibration standard errors.

\subsection{Surface sediment at site PL-1}

The $\mathrm{U}_{37}^{\mathrm{K}}{ }^{-}, \mathrm{TEX}_{86}^{\mathrm{H}}{ }^{-}$and $\mathrm{TEX}_{86}^{\mathrm{L}}$-based temperatures at the core-top sample (surface sediment, $0-1 \mathrm{~cm}$ ) of core $\mathrm{PL}-1$ are $22.3^{\circ} \mathrm{C}, 22.6^{\circ} \mathrm{C}$ and $22.8^{\circ} \mathrm{C}$, respectively. These temperatures agreed with mean annual SST $\left(22.4^{\circ} \mathrm{C}\right.$; Japan Oceanographic Data Center; available at http://www.jodc.go.jp/index.html), the SSTs in May and November or the temperature from June to November at depths of 50-70 m.

\section{Discussion}

\subsection{Production of alkenones in surface water}

The maximum alkenone concentration appeared in the top $25 \mathrm{~m}$ and the $\mathrm{U}_{37}^{\mathrm{K}}$ values were consistent with measured in-situ water temperatures in the interval, implying that the 
alkenones were produced mainly in surface water in the May 2008 spring bloom. Alkenones are produced mostly by Emiliania huxleyi and Gephyrocapsa species in marine environment (Marlowe et al., 1984; Volkman et al., 1995). A sediment trap experiment conducted in 1993 and 1994 in the central Okinawa Trough indicated that the sinking flux of E. huxleyi was maximal in spring (Tanaka, 2003).

The concentration of $n-22: 6$ showed a downward decreasing trend as also seen in alkenones at St. 12, St. 8 and St. 1 (Fig. 2). The $n-22: 6$ is a specific biomarker of phytoplankton (Volkman et al., 1989). The decreasing trend most likely reflects the production of $n-22: 6$ by phytoplankton in the surface water. Because the major fatty acid in Emiliania huxleyi and Gephyrocapsa oceanica is n-22:6 (Yamamoto et al., 2000), Emiliania huxleyi and Gephyrocapsa contributed to the production of $n-22: 6$. The relative abundance of alkenones to $n-22: 6$ was higher at trough sites St. 1 and St. 8 than those at a slope site St. 12 and a shelf site St. 11 (Fig. 3), suggesting that the contribution of Emiliania huxleyi and Gephyrocapsa was larger in the Okinawa Trough than in slope and shelf areas.

The depth profile of $\mathrm{U}_{37}^{\mathrm{K}}$ demonstrated that its value decreased in harmony with the measured in-situ water temperature from the surface to a depth of ca. 20-100 m (Fig. 2). This correspondence was observed within the top $20 \mathrm{~m}$ at shelf site St. 11, within the top $50 \mathrm{~m}$ at slope site St. 12 and within the top 80-100 m at trough sites St. 1 and St. 8. These intervals likely indicate that photosynthesis was active in the photic zone. Changes in the depth interval were consistent with the trend in surface water turbidity decreasing toward offshore sites (Yanagi et al.1996). Below this interval, $\mathrm{U}_{37}^{\mathrm{K}}$-based temperatures were higher than measured in-situ water temperature (ca. $20^{\circ} \mathrm{C}$ for most samples).

In the northern Okinawa Trough, the $\mathrm{U}_{37}^{\mathrm{K}}$-based temperature of surface sediment taken from site PL-1 close to St. 1 and St. 8 was $22.3^{\circ} \mathrm{C}\left(\mathrm{U}_{37}^{\mathrm{K}}=0.798\right.$; Table 2$)$. This value agrees with the $\mathrm{U}_{37}^{\mathrm{K}}$, values in POM from the 5-20 m interval at St. 1 and St. 8 (21.9-22.2 $\left.{ }^{\circ} \mathrm{C}\right)$. This agreement suggests that the sediment $\mathrm{U}_{37}^{\mathrm{K}}$ value reflects the temperature of the surface 
mixed layer in the spring bloom.

4.2. $T E X_{86}^{\mathrm{H}}$ and $T E X_{86}^{\mathrm{L}}$

$\mathrm{TEX}_{86}^{\mathrm{H}}$ and $\mathrm{TEX}_{86}^{\mathrm{L}}$ disagreed in the top 10 meters at all locations; $\mathrm{TEX}_{86}^{\mathrm{H}}$-based temperatures were $5-9^{\circ} \mathrm{C}$ lower than $\mathrm{TEX}_{86}^{\mathrm{L}}$-based temperatures (Fig. 3). Kim et al. (2010) recommended that $\mathrm{TEX}_{86}^{\mathrm{H}}$, which includes the abundance of crenarchaeol regio-isomer, be used in tropical and subtropical regions $\left(>15^{\circ} \mathrm{C}\right)$ and that $\mathrm{TEX}_{86}^{\mathrm{L}}$, which excludes the abundance of crenarchaeol regio-isomer, be used in polar and subpolar regions $\left(<15^{\circ} \mathrm{C}\right)$. In this study, $\mathrm{TEX}_{86}^{\mathrm{L}}$-based temperatures were closer to in-situ temperatures in the surface waters of top 10 meters than were $\mathrm{TEX}_{86}^{\mathrm{H}}$-based temperatures. This suggests that $\mathrm{TEX}_{86}^{\mathrm{L}}$ is more reliable than $\mathrm{TEX}_{86}^{\mathrm{H}}$ in the surface water. On the other hands, $\mathrm{TEX}_{86}^{\mathrm{H}}$ and $\mathrm{TEX}_{86}^{\mathrm{L}}$ showed agreements in deeper waters. The surface water originates from the CDW, and the deeper water is the mixture of the Kuroshio water and the Yellow Sea central cold water (Ichikawa and Beardsley, 2002). Kim et a. (2010) indicated that crenarchaeol regio-isomer plays a more important role for temperature adaptation in subtropical oceans than subpolar oceans because there may be differences in membrane adaptation of the resident Thaumarchaeota communities at different temperatures. The difference in the behaviors of $\mathrm{TEX}_{86}^{\mathrm{H}}$ and $\mathrm{TEX}_{86}^{\mathrm{L}}$ indices between the surface and deeper waters found in this study may be attributed to the difference of Thaumarchaeota community between the cold CDW and the tropical Kuroshio water. In this study, we use $\mathrm{TEX}_{86}^{\mathrm{L}}$ in the surface water and $\mathrm{TEX}_{86}^{\mathrm{H}}$ in the deeper water for further discussion.

\subsection{Production and advection of GDGTs}

GDGTs showed a depth profile different from those of alkenones and PUFAs. The concentration was low in surface water and reached a maximum at 50-100 m depth (Fig. 3). 
At the slope site (St. 12), the GDGT concentration showed a broad maximum from 50 to 198 m centered at $99 \mathrm{~m}$ (Fig. 3). In this interval, $\operatorname{TEX}_{86}^{\mathrm{H}}$-based temperatures agreed with measured in-situ water temperatures (Fig. 3). The agreement of measured and $\mathrm{TEX}_{86}^{\mathrm{H}}$-based temperatures suggests the in-situ production of GDGTs. At the shelf site (St. 11), the GDGT concentration showed a maximum at $74 \mathrm{~m}$, and the $\mathrm{TEX}_{86}^{\mathrm{H}}$-based temperature at the maximum agreed with in-situ water temperatures (Fig. 3), suggesting the in-situ production of GDGTs. At the trough sites, the maximal peaks of GDGT concentration appeared at $50 \mathrm{~m}$ at St. 8, and $99 \mathrm{~m}$ at St. St. 1, but they were much weaker than those at St. 11 and St. 12 (Fig. 3), suggesting that in-situ production of GDGTs in the study period was not significant in Okinawa Trough stations.

At St. 11 and St. $8, \mathrm{TEX}_{86}^{\mathrm{L}}$-based temperatures in the surface waters were $12.8^{\circ} \mathrm{C}$ and $16.4^{\circ} \mathrm{C}$, respectively, which were lower than in-situ water temperatures $\left(19.3^{\circ} \mathrm{C}\right.$ and $20.5^{\circ} \mathrm{C}$, respectively). This disagreement suggests that GDGTs were produced in a cooler season or transported from a cooler location. February SSTs were $\sim 14^{\circ} \mathrm{C}$ and $\sim 17^{\circ} \mathrm{C}$ at these sites, respectively (Japan Oceanographic Data Center; http://www.jodc.go.jp/index.html). It is thus possible that the GDGTs have the winter temperature signal if GDGTs were produced in winter and preserved without the addition of GDGTs formed in spring. Alternatively, low salinity $(<33.8)$ is the characteristic of surface water in this area, and low-salinity water originates from the CDW, the mixture of Changjiang freshwater with saline shelf water along the Chinese coast, and is advected by an eastward current (Ichikawa and Beardsley, 2002). The temperature and salinity are generally lower on the continental shelf than in the Okinawa Trough (Japan Oceanographic Data Center; available at http://www.jodc.go.jp/index.html). The SST near the Chaingjiang estuary in the ECS is about $15^{\circ} \mathrm{C}$ (NOAA, 1998), which almost corresponds to the $\mathrm{TEX}_{86}^{\mathrm{L}}$-based temperature $\left(\sim 13^{\circ} \mathrm{C}\right)$ in surface water at the shelf site (St. 11; Fig. 3). It is thus also possible that the advection of GDGTs from the CDW results in cooler $\mathrm{TEX}_{86}^{\mathrm{L}}$-based temperature in the surface waters. In contrast to St. 11 and St. 8, TEX ${ }_{86}^{\mathrm{L}}$ 
-based temperature in the surface water at St. 12 corresponded to in-situ water temperature (Fig. 3). We suppose that newly-produced GDGTs had a spring in-situ temperature signal that overprinted a cooler temperature signal.

At the slope site (St. 12) and the Okinawa Trough site (St. 1), $\mathrm{TEX}_{86}^{\mathrm{H}}$-based temperatures were nearly constant in the water column deeper than 200-300 $\mathrm{m}$ and higher than in-situ water temperatures (Fig. 3). Because the water temperatures are stable and show little seasonal changes (NOAA, 1998), the difference between in-situ and $\mathrm{TEX}_{86}^{\mathrm{H}}$-based temperatures indicates that the GDGTs were not produced at the sampling depth. Wuchter et al. (2005) investigated $\mathrm{TEX}_{86}$ in POM at different depths at several world ocean sites and found that the $\mathrm{TEX}_{86}$ values in POM were nearly constant at different depths and that the estimated temperatures agreed with mean annual surface temperatures. On a basis of this observation, they hypothesized that Thaumarchaeota cells produced in surface water are delivered to deeper water by absorption to larger molecules produced by phytoplankton and/or grazing by zooplankton and subsequent settling (Wuchter et al., 2005). A sediment trap study in the north-western Pacific showed that the flux-averaged $\mathrm{TEX}_{86}$ in sinking particles were nearly constant at different depth and agreed with mean annual SST, and also that the sinking flux of GDGTs decreased with increasing depth due to the degradation and disaggregation of sinking particles (Yamamoto et al., 2012). These results suggest that the GDGTs found in the deeper water column at St. 12 and St. 1 were delivered from the surface water. At both St. 12 and St. 1, the $\mathrm{TEX}_{86}^{\mathrm{H}}$-based temperatures in the deeper water column $(\sim 300-700 \mathrm{~m})$ corresponded to the mean annual SSTs. This suggests that the residence time of suspended GDGTs in the deep water column is large enough to mix the GDGTs produced in different seasons.

At the Okinawa Trough site (St. 1), $\mathrm{TEX}_{86}^{\mathrm{H}}$-based temperatures $\left(22.7^{\circ} \mathrm{C}\right)$ at the deepest sample $(693 \mathrm{~m})$ agreed with those of surface sediment $(758 \mathrm{~m})$ at the nearby site PL-1 $\left(22.6^{\circ} \mathrm{C}\right.$ and $22.8^{\circ} \mathrm{C}$, respectively). This indicates that the GDGTs in surface sediments 
preserve a temperature signal propagated from the surface water.

\section{Conclusions}

GDGTs in the water column showed a concentration maximum at 74-99 $\mathrm{m}$ depth, and the $\mathrm{TEX}_{86}^{\mathrm{H}}$-based temperatures agreed with measured in-situ water temperatures, suggesting the in-situ production of GDGTs in the depth interval. The low-salinity surface water above $20 \mathrm{~m}$ depth was characterized by low GDGT concentrations and low $\mathrm{TEX}_{8}^{\mathrm{L}}$-based temperatures, suggesting either the production of GDGTs in winter season or the lateral advection of GDGTs by an eastward current from the near-shore area of the East China Sea. TEX $86^{-}$-based temperatures were nearly constant in the water column deeper than 200-300 m and basically corresponded to temperatures at the surface and near-surface waters rather than in situ temperatures. This observation is consistent with a hypothesis that Thaumarchaeota cells produced in surface waters are delivered to deeper water and also indicates that the residence time of suspended GDGTs in the deep water column is large enough to mix the GDGTs produced in different seasons.

\section{Acknowledgements}

We thank all the participants and onboard staff of cruise KY07-04 cruise. We also appreciate the help provided by Tatsufumi Okino and Masao Minagawa (Hokkaido University) with analysis. Special thanks go to Kyung-Hoon Shin and Suk-Hee Yoon (Hanyang University) for discussion. Comments by two anonymous reviewers improved this manuscript very much. The study was supported by a grant-in-aid for Scientific Research (A) the Japan Society for the Promotion of Science, No. 19204051 (to M.Y.).

\section{References}

Agogué H, Brink M, Dinasquet J, Herndl GJ (2008) Major gradients in putatively nitrifying 
and non-nitrifying Archaea in the deep North Atlantic. Nature 456: 788-792.

Baltar F, Aristegui J, Gasol JM, Hernandez-Leon S, Herndl GJ (2007) Strong coast-ocean and surface-depth gradients in prokaryotic assemblage structure and activity in a coastal transition zone region. Aquatic Microbial Ecology 50: 63-74.

Beman JM, Popp BN, Francis CA (2008) Molecular and biogeochemical evidence for ammonia oxidation by marine Crenarchaeota in the Gulf of California. The ISME Journal 2: 429-441.

Blainey PC, Mosier AC, Potanina A, Francis CA, Quake SR (2011) Genome of a low-salinity ammonia-oxidizing Archaeon determined by single cell and metagenomic analysis. PLoS ONE 6: 1-12.

Brassell SC, Eglinton G, Marlowe IT, Pflaumann U, Sarnthein M (1986) Molecular stratigraphy: a new tool for climatic assessment. Nature 320: 129-133.

Brochier-Armanet C, Boussau B, Gribaldo S, Forterre P (2008) Mesophilic crenarchaeota: proposal for a third archaeal phylum, the Thaumarchaeota. Nature Reviews Microbiology 6: $245-252$.

Coolen MJL, Abbas B, van Bleijswijk J, Hopmans EC, Kuypers MMM, Wakeham SG, Sinninghe Damsté JS (2007) Putative ammonia-oxidizing Crenarchaeota in suboxic waters of the Black Sea: a basin-wide ecological study using $16 \mathrm{~S}$ ribosomal and functional genes and membrane lipids. Environmental Microbiology 9: 1001-1016.

Furuya K, Hayashi M, Yabushita Y, Ishikawa A (2003) Phytoplankton dynamics in the East China Sea in spring and summer as revealed by HPLC-derived pigment signatures. Deep-Sea Research II 50: 367-387.

Hallam SJ, Mincer TJ, Schleper C, Preston CM, Roberts K, Richardson PM, DeLong EF (2006) Pathway of carbon assimilation and ammonia oxidation suggested by environmental genomic analyses of marine Crenarchaeota. PLoS Biology 4: 520-536.

Herfort L, Schouten S, Boon JP, Sinninghe Damsté JS (2006) Application of the TEX 86 
temperature proxy to the southern North Sea. Organic Geochemistry 37: 1715-1726.

Herndl GJ, Reinthaler TR, Teira E, van Aken H, Veth C, Pernthaler A, Pernthaler J (2005) Contribution of Archaea to total prokaryotic production in the deep Atlantic Ocean. Applied and Environmental Microbiology 71: 2303-2309.

Hopmans EC, Schouten S, Pancost R, van der Meer MTJ, Sinninghe Damsté JS, (2000) Analysis of intact tetraether lipids in archaeal cell material and sediments by high performance liquid chromatography/atmospheric pressure chemical ionization mass spectrometry. Rapid Communications in Mass Spectrometry 14: 585-589.

Hopmans EC, Weijers JWH, Schefuss E, Herfort L, Sinninghe Damsté JS, Schouten S (2004) A novel proxy for terrestrial organic matter in sediments based on branched and isoprenoid tetraether lipids. Earth and Planetary Science Letters 224: 107-116.

Huguet C, Hopmans EC, Febo-Ayala W, Thompson DH, Sinninghe Damsté JS, Schouten S (2006a) An improved method to determine the absolute abundance of glycerol dibiphytanyl glycerol tetraether lipids. Organic Geochemistry 37: 1036-1041

Huguet C, Kim JH, Sinninghe Damsté JS, Schouten S, (2006b) Reconstruction of sea surface temperature variations in the Arabian Sea over the last $23 \mathrm{kyr}$ using organic proxies $\left(\right.$ TEX $_{86}$ and $\left.\mathrm{U}_{37}^{\mathrm{K}^{\prime}}\right)$. Paleoceanography 21: PA300S.

Ichikawa H, Beardsley RC (2002) The current system in the Yellow and East China Seas. Journal of Oceanography 58: 77-92.

Japan Oceanographic Data Center (JODC) 1906-2003. Oceanographic data, monthly sea-surface temperature in the East China Sea, http://www.jodc.go.jp/index.html, Japan Hydrographic Association, Tokyo, Japan.

Karner MB, DeLong EF, Karl DM (2001) Archaeal dominance in the mesopelagic zone of the Pacific Ocean. Nature 409: 507-510.

Kim JH, Schouten S, Hopmans EC, Donner B, Sinninghe Damsté JS (2008) Global sediment core-top calibration of the $\mathrm{TEX}_{86}$ paleothermometer in the ocean. Geochimica et 
Cosmochimica Acta 72: 1154-1173.

Kim JH, van der Meer J, Schouten S, Helmke P, Willmott V, Sangiorgi F, Koc N, Hopmans EC, Sinninghe Damsté JS (2010) New indices and calibrations derived from the distribution of crenarchaeal isoprenoid tetraether lipids: Implications for past sea surface temperature reconstructions. Geochimica et Cosmochimica Acta 74: 4639-4654.

Kondo M (1985) Oceanographic investigations of fishing grounds in the East China Sea and the Yellow Sea-I, Characteristics of the mean temperature and salinity distributions measured at $50 \mathrm{~m}$ and near the bottom. Bulletin of the Seikai Region Fishery Research Laboratory 62: 19-55 (in Japanese with English abstract).

Könneke M, Bernhard AE, de la Torre JR, Walker CB, Waterbury JB, Stahl DA (2005) Isolation of an autotrophic ammonia-oxidizing archaeon. Nature 437: 543-546.

Marlowe IT, Brassell SC, Eglinton G, Green JC (1984) Long chain unsaturated ketones and esters in living algae and marine sediments. Organic Geochemistry 6: 135-141.

Murray AE, Blakis A, Massana R, Strawzewski S, Passow U, Alldredge A, De Long EF (1999) A time series assessment of planktonic archaeal variability in the Santa Barbara Channel. Aquatic Microbial Ecology 20: 129-145.

NOAA (1998) http://iridl.ldeo.columbia.edu/SOURCES/.NOAA/.NODC/.WOA98/

Ouverney CC, Fuhrman JA (2000) Marine planktonic Archaea take up amino-acids. Applied Environmental Microbiology 66: 4829-4833.

Park BJ, Park SJ, Yoon DN, Schouten S, Sinninghe Damsté JS, Rhee SK (2010) Cultivation of autotrophic ammonia-oxidizing Archaea from marine sediments in coculture with sulfur-oxidizing bacteria. Applied and Environmental Microbiology 76: 7575-7587.

Patwardhan AP, Thompson DH (1999) Efficient synthesis of 40- and 48-membered tetraether macrocyclic bisphosphocholines. Organic Letters 1: 241-243.

Pitcher A, Wuchter CW, Siedenberg K, Schouten S, Sinninghe Damsté JS (2011) Crenarchaeol tracks winter blooms of ammonia-oxidizing Thaumarchaeota in the coastal 
North Sea. Limnology and Oceanography 56: 2308-2318.

Prahl FG, Wakeham SG (1987) Calibration of unsaturation patterns in long-chain ketone compositions for palaeotemperature assessment. Nature 330: 367-369.

Prahl FG, Muehlhausen LA, Zahnle DL (1988) Further evaluation of long-chain alkenones as indicators of paleoceanographic conditions. Geochimica et Cosmochimica Acta 52: $2303-2310$.

Schouten S, Hopmans EC, Pancost RD, Sinninghe Damsté JS (2000) Widespread occurrence of structurally diverse tetraether membrane lipids: Evidence for the ubiquitous presence of low-temperature relatives of hyperthermophiles. Proceedings of the National Academy of Science, USA 97: 14421-14426.

Schouten S, Hopmans EC, Schefuß E, Sinninghe Damsté JS (2002) Distributional variations in marine crenarchaeotal membrane lipids: a new tool for reconstructing ancient sea water temperatures? Earth and Planetary Science Letters 204: 265-274.

Schouten S, Huguet C, Hopmans EC, Kienhuis MVM, Sinninghe Damsté JS (2007) Analytical methodology for $\mathrm{TEX}_{86}$ paleothermometry by high performance liquid chromatography/atmospheric pressure chemical ionization-mass spectrometry. Analytical Chemistry 79: 2940-2944.

Sicre MA, Tian RC, Saliot A (1994) Distribution of sterols in the suspended particles of the Chang Jiang Estuary and adjacent East China Sea. Organic Geochemistry 21: 1-10.

Sinninghe Damsté JS, Rijpstra WIC, Reichart GJ (2002a) The influence of oxic degradation on the sedimentary biomarker record II. Evidence from Arabian Sea sediments. Geochemica et Cosmochimica Acta 66: 2737-2754.

Sinninghe Damsté JS, Schouten S, Hopmans EC, van Duin ACT, Geenevasen JAJ, (2002b) Crenarchaeol: the characteristic core glycerol dibiphytanyl glycerol tetraether membrane lipid of cosmopolitan pelagic crenarchaeota. Journal of Lipid Research 43: 1641-1651.

Spang A, Hatzenpichler R, Brochier-Armanet C, Rattei T, Tischler P, Spieck E, Streit W, 
Stahl DA, Wagner M, Schleper C (2010) Distinct gene set in two different lineages of ammonia-oxidizing archaeal supports the phylum Thaumarchaeota. Trends in Microbiology 18: 331-340.

Takagi M, Fukushima H, Asanuma I, Ishizaka I (1993) Northwestern Pacific Coastal Zone Color Scanner Monthly Composite (1978-1986), a CD-ROM Publication.

Tanaka Y, (2003) Coccolith fluxes and species assemblages at the shelf edge and in the Okinawa Trough of the East China Sea. Deep-Sea Res. II 50: 503-511.

Turich C, Freeman KH, Bruns MA, Conte M, Jones AD, Wakeham SG (2007) Lipids of marine Archaea: Patterns and provenance in the water-column and sediments. Geochimica et Cosmochimica Acta 71: 3272-3291.

Verala MM, van Aken HM, Sintes E, Herndl GJ (2008) Latitudinal trends of Crenarchaeota and Bacteria in the meso- and bathypelagic water masses of the Eastern North Atlantic. Environmental Microbiology 10: 110-124.

Volkman JK, Jeffrey SW, Nichols PD, Rogers GI, Garland CD (1989) Fatty acid and lipid composition of 10 species of microalgae used in mariculture. Journal of Experimental marine Biology and Ecology 128: 219-240.

Volkman JK, Barrett SM, Blackburn SI, Sikes EL (1995) Alkenones in Gephyrocapsa oceanica: Implications for studies of paleoclimate. Geochimica et Cosmochimica Acta 59: 513-520.

Weijers JWH, Schouten S, Spaargaren OC, Sinninghe Damsté JS (2006) Occurrence and distribution of tetraether membrane in soils: Implications for the use of the BIT index and the TEX $_{86}$ SST proxy. Organic Geochemistry 37: 1680-1693.

Wuchter C, Schouten S, Coolen MJL, Sinninghe Damsté JS (2004) Temperature-dependant variation in the distribution of tetraether membrane lipids of marine Crenarchaeota: Implications for $\mathrm{TEX}_{86}$ paleothermometry. Paleoceanography 19: PA4028. Wuchter C, Schouten S, Wakeham SG, Sinninghe Damsté JS (2005) Temporal and spatial variation in 
tetraether membrane lipids of marine Crenarchaeota in particulate organic matter: Implications for $\mathrm{TEX}_{86}$ paleothermometry. Paleoceanography 20: PA3013.

Wuchter C, Abbas B, Coolen MJL, Herfort L, van Bleijswijk J, Timmers P, Strous M, Teira E, Herndl GJ, Middelburg JJ, Schouten S, Sinninghe Damsté JS (2006) Archaeal nitrification in the ocean. Proceedings of National Academy of Science 103: 12317-12322.

Yamamoto M, Shiraiwa Y, Inouye I (2000) Physiological responses of lipids in Emiliania huxleyi and Gephyrocapsa oceanica (Haptophyceae) to growth status and their implications for alkenone paleothermometry. Organic Geochemistry 31: 799-811.

Yamamoto M, Shimamoto A., Fukuhara T, Tanaka Y, Ishizaka J (2012) Glycerol dialkyl glycerol tetraethers and the $\mathrm{TEX}_{86}$ index in sinking particles in the western North Pacific. Organic Geochemistry, in press, 10.1016/j.orggeochem.2012.04.010.

Yanagi T, Takahashi S, Hoshika A, Tanimoto T (1996) Seasonal variation in the transport of suspended matter in the East China Sea. Journal of Oceanography 52: 539-552.

Zhang Y, Sintes E, Chen J, Zhnag Y, Dai M, Jiao N, Herndl, GJ (2009) Role of mesoscale cyclonic eddies in the distribution and activity of Archaea and Bacteria in the South China Sea. Aquatic Microbial Ecology 56: 65-79. 


\section{Table captions}

\section{Table 1}

Study sites.

\section{Table 2}

Concentration of isoprenoid GDGTs as a basis for the seawater $\mathrm{TEX}_{86}, \mathrm{TEX}_{86}^{\mathrm{L}}, \mathrm{TEX}_{86}^{\mathrm{H}}$, BIT, alkenone concentration and $\mathrm{U}_{37}^{\mathrm{K}^{\prime}}$ in POM and a surface sediment $(0-1 \mathrm{~cm}$ depth) from the East China Sea (n.d., not detected). 
Table 1

\begin{tabular}{ccccc}
\hline Station & Location & Water depth $(\mathrm{m})$ & Sampling date & Setting \\
\hline St. 11 & $31^{\circ} 30.03^{\prime} \mathrm{N}, 126^{\circ} 29.85^{\prime} \mathrm{E}$ & 91 & $27-$ May-08 & Shelf \\
St. 12 & $31^{\circ} 29.99^{\prime} \mathrm{N}, 128^{\circ} 30.31^{\prime} \mathrm{E}$ & 565 & $28-$ May-08 & Slope \\
St. 8 & $31^{\circ} 44.26^{\prime} \mathrm{N}, 128^{\circ} 56.48^{\prime} \mathrm{E}$ & 870 & $26-$ May-08 & Trough \\
St. 1 & $31^{\circ} 40.68^{\prime} \mathrm{N}, 129^{\circ} 01.90^{\prime} \mathrm{E}$ & 730 & $25-\mathrm{May}-08$ & Trough \\
\hline PL-1 & $31^{\circ} 38.35^{\prime} \mathrm{N}, 128^{\circ} 56.64^{\prime} \mathrm{E}$ & 758 & $15-\mathrm{Feb}-07$ & Trough \\
\hline
\end{tabular}


Table 2

\begin{tabular}{|c|c|c|c|c|c|c|c|c|}
\hline Station & $\begin{array}{l}\text { Depth } \\
(\mathrm{m})\end{array}$ & $\begin{array}{c}\text { Isop. GDGT } \\
(n g / L)\end{array}$ & $\mathrm{TEX}_{86}$ & $\mathrm{TEX}_{86}{ }^{\mathrm{H}}$ & $\mathrm{TEX}_{86}{ }^{\mathrm{L}}$ & BIT & $\begin{array}{c}\text { Alkenones } \\
\text { (ng/L) }\end{array}$ & $\mathrm{U}_{37^{\prime}}^{\mathrm{K}}$ \\
\hline \multirow[t]{6}{*}{ St. 11} & 5.1 & 0.80 & 0.315 & -0.502 & -0.505 & 0 & 12.79 & 0.623 \\
\hline & 10.4 & 0.94 & 0.323 & -0.491 & -0.508 & 0 & 11.56 & 0.599 \\
\hline & 24.8 & 7.19 & 0.418 & -0.379 & -0.516 & 0 & 27.95 & 0.513 \\
\hline & 49.3 & 24.48 & 0.386 & -0.413 & -0.554 & 0.001 & n.d. & n.d. \\
\hline & 73.9 & 38.42 & 0.426 & -0.370 & -0.528 & 0.006 & n.d. & n.d. \\
\hline & 85.9 & 35.21 & 0.420 & -0.377 & -0.541 & 0.004 & 5.05 & 0.726 \\
\hline \multirow[t]{11}{*}{ St. 12} & 4.9 & 0.24 & 0.418 & -0.378 & -0.378 & 0.034 & 30.90 & 0.854 \\
\hline & 10.7 & 0.19 & 0.425 & -0.371 & -0.371 & 0 & 41.06 & 0.847 \\
\hline & 19.8 & 0.88 & 0.585 & -0.233 & -0.324 & 0 & 25.75 & 0.821 \\
\hline & 49.6 & 1.70 & 0.536 & -0.271 & -0.445 & 0 & 12.03 & 0.628 \\
\hline & 79.5 & 5.08 & 0.515 & -0.289 & -0.446 & 0 & 5.54 & 0.676 \\
\hline & 99.0 & 15.23 & 0.479 & -0.319 & -0.482 & 0 & 5.10 & 0.724 \\
\hline & 148.6 & 8.62 & 0.476 & -0.322 & -0.473 & 0 & 4.25 & 0.741 \\
\hline & 198.1 & 1.94 & 0.577 & -0.239 & -0.370 & 0 & 1.84 & 0.849 \\
\hline & 297.3 & 2.68 & 0.601 & -0.221 & -0.353 & 0 & n.d. & n.d. \\
\hline & 495.5 & 4.43 & 0.574 & -0.241 & -0.379 & 0 & n.d. & n.d. \\
\hline & 557.9 & 4.62 & 0.577 & -0.239 & -0.374 & 0 & 2.92 & 0.702 \\
\hline \multirow[t]{8}{*}{ St. 8} & 5.0 & 0.48 & 0.379 & -0.421 & -0.452 & 0 & 151.21 & 0.789 \\
\hline & 9.5 & 0.62 & 0.342 & -0.466 & -0.512 & 0 & 156.47 & 0.788 \\
\hline & 19.9 & 0.88 & 0.442 & -0.355 & -0.470 & 0 & 209.44 & 0.781 \\
\hline & 49.6 & 4.61 & 0.503 & -0.298 & -0.500 & 0 & 62.31 & 0.722 \\
\hline & 73.7 & 4.27 & 0.514 & -0.289 & -0.463 & 0 & 20.43 & 0.675 \\
\hline & 99.1 & 3.11 & 0.510 & -0.293 & -0.474 & 0 & 9.52 & 0.680 \\
\hline & 148.7 & 3.28 & 0.518 & -0.285 & -0.443 & 0 & 5.48 & 0.683 \\
\hline & 198.1 & 3.15 & 0.551 & -0.258 & -0.434 & 0 & 4.15 & 0.703 \\
\hline St. 1 & 5.1 & 0.68 & 0.426 & -0.371 & -0.414 & 0 & 135.71 & 0.785 \\
\hline
\end{tabular}




\begin{tabular}{rrrrrrrrr}
9.3 & 0.57 & 0.434 & -0.362 & -0.413 & 0 & 124.21 & 0.794 \\
19.8 & 1.18 & 0.449 & -0.348 & -0.445 & 0 & 112.02 & 0.782 \\
49.4 & 2.93 & 0.395 & -0.403 & -0.471 & 0 & 26.37 & 0.698 \\
74.0 & 2.42 & 0.362 & -0.442 & -0.461 & 0 & 11.40 & 0.686 \\
& 98.8 & 3.10 & 0.518 & -0.286 & -0.447 & 0 & 8.82 & 0.658 \\
& 148.6 & 2.85 & 0.451 & -0.346 & -0.436 & 0 & 5.67 & 0.737 \\
& 198.2 & 2.58 & 0.451 & -0.346 & -0.427 & 0 & 4.03 & 0.697 \\
& 297.7 & 2.51 & 0.530 & -0.276 & -0.368 & 0 & 1.66 & 0.682 \\
& 396.1 & 2.45 & 0.538 & -0.269 & -0.357 & 0 & 1.14 & 0.650 \\
& 495.8 & 2.33 & 0.538 & -0.269 & -0.329 & 0 & 1.54 & 0.662 \\
\hline PL-1 & 6.21 & 0.585 & -0.233 & -0.362 & 0 & 1.84 & 0.727 \\
\hline
\end{tabular}

n.d. $=$ not determined 
Figure captions

Fig. 1. Map showing locations of study sites, (top) the distribution of montly mean May temperature at 0-m depth (Data from Japan Oceanographic Data Center, 1906-2003) and (bottom) topography in the East China Sea (ECS). KSW = Kuroshio water. CDW = Changjiang diluted water. YSCCW $=$ Yellow Sea central cold water. KBCWK $=$ Kuroshio branch current west of Kyushu (Ichikawa and Beardsley, 2002). Open circles in bottom map indicate the location of water samples, and a gray circle indicates the location of a sediment core.

Fig. 2. Depth variation in (top) measured salinity and concentration of total alkenones and $n$ - $\mathrm{C}_{22: 6} \mathrm{FA}(n-22: 6)$, and (bottom) measured temperature and $\mathrm{U}_{37}^{\mathrm{K}}$-based temperature at St. 11 on the continental shelf, St. 12 on the continental slope, and St. 8 and St. 1 in the Okinawa Trough.

Fig. 3. Depth variation in (top) measured salinity andtotal GDGT concentration, and (bottom) measured temperature and $\mathrm{TEX}_{86}^{\mathrm{H}}$ - and $\mathrm{TEX}_{86}^{\mathrm{L}}$-based temperatures at St. 11 on the continental shelf, St. 12 on the continental slope, and St. 8 and St. 1 in the Okinawa Trough. GDGT concentrations at St. 8 and St. 1 are shown by signal amplified by 5 times (GDGT $\mathrm{x}$ 5). 

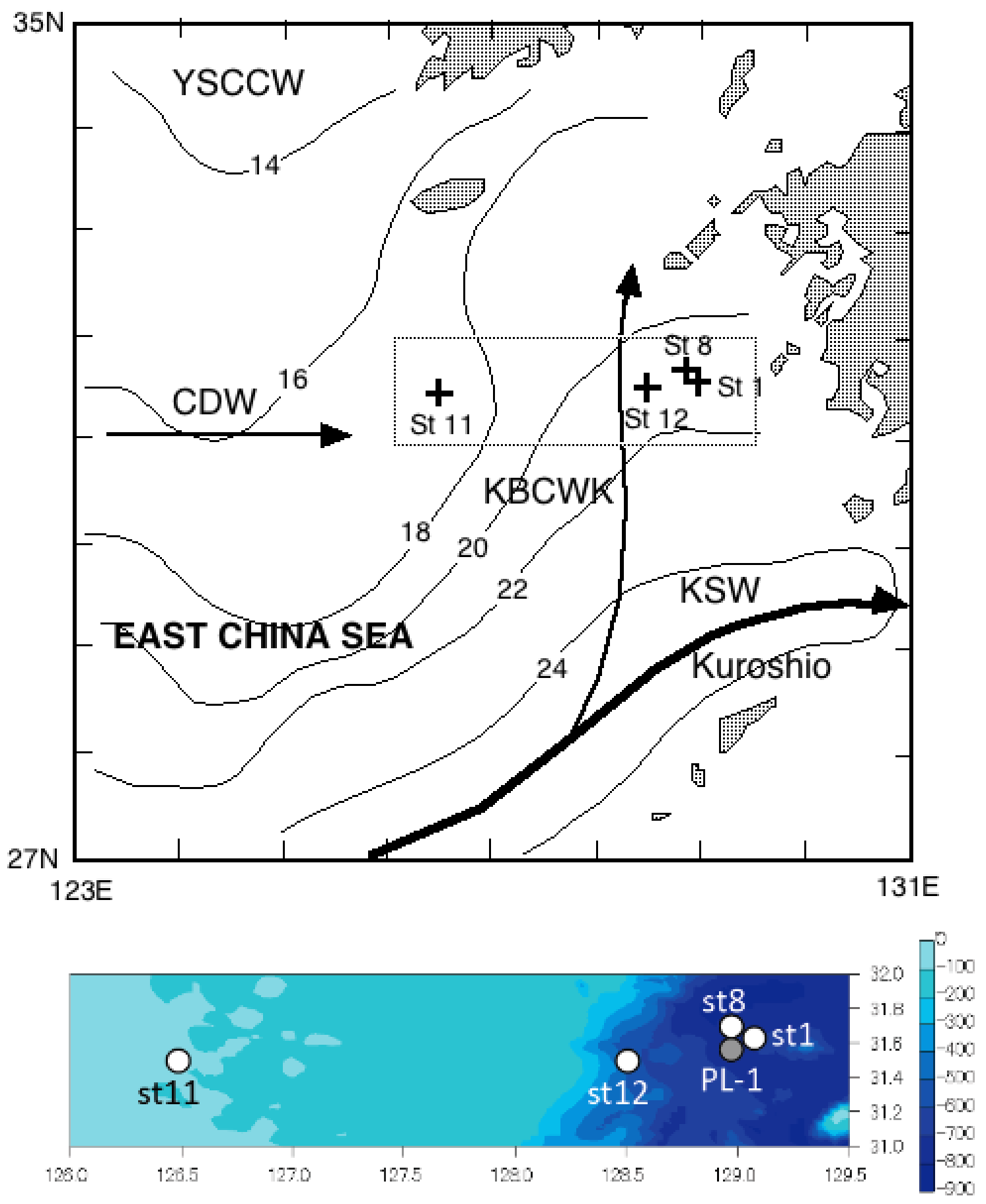

Fig. 1 


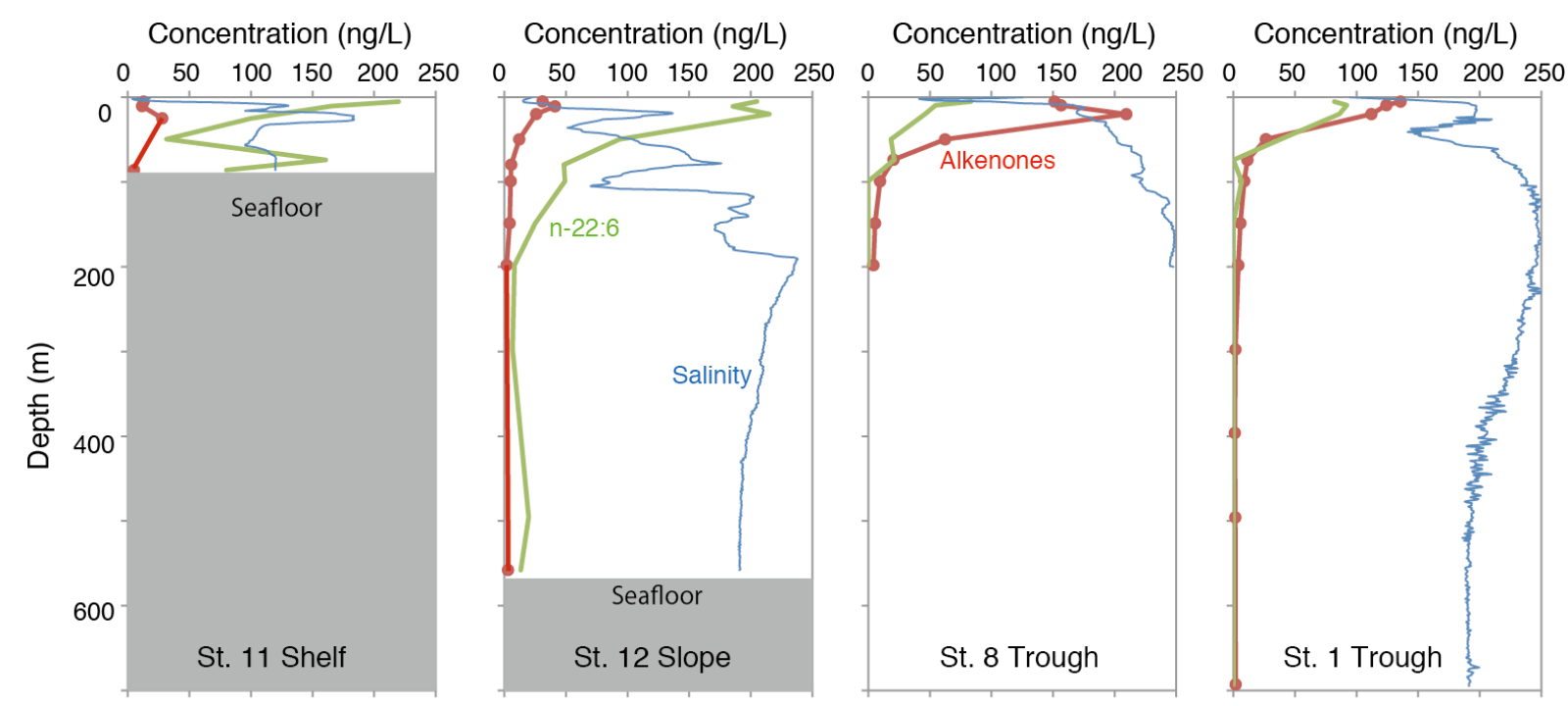

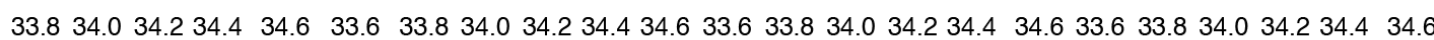
Salinity Salinity

Salinity

Salinity

Temperature $\left({ }^{\circ} \mathrm{C}\right)$

Temperature $\left({ }^{\circ} \mathrm{C}\right)$

Temperature $\left({ }^{\circ} \mathrm{C}\right)$

Temperature $\left({ }^{\circ} \mathrm{C}\right)$
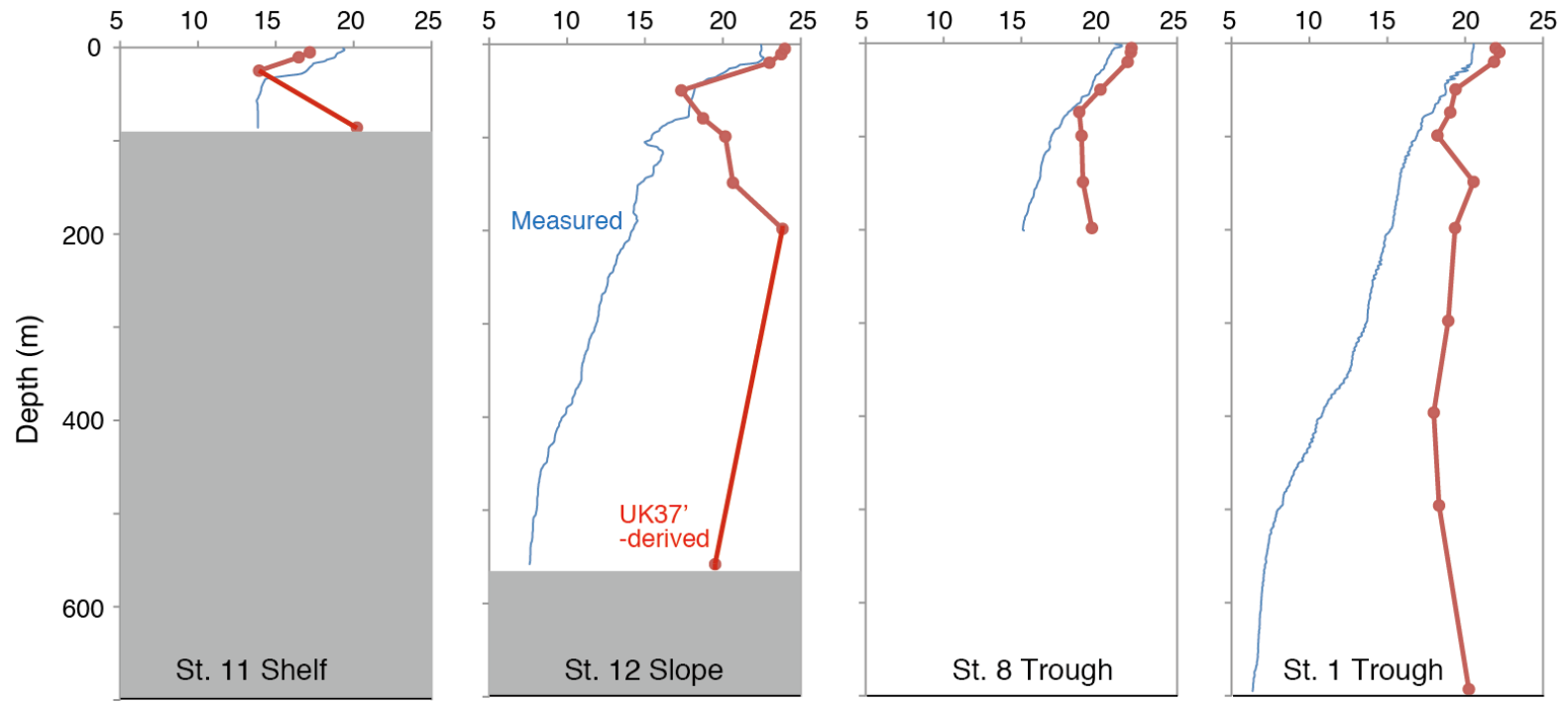

Fig. 2 


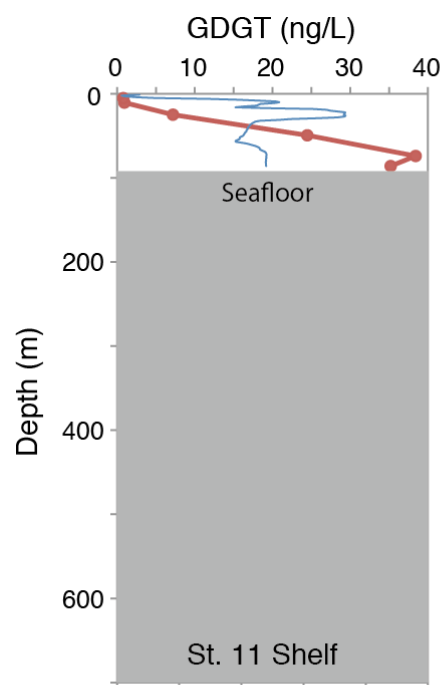

$33.6 \quad 33.8 \quad 34.034 .234 .4 \quad 34.6$ Salinity

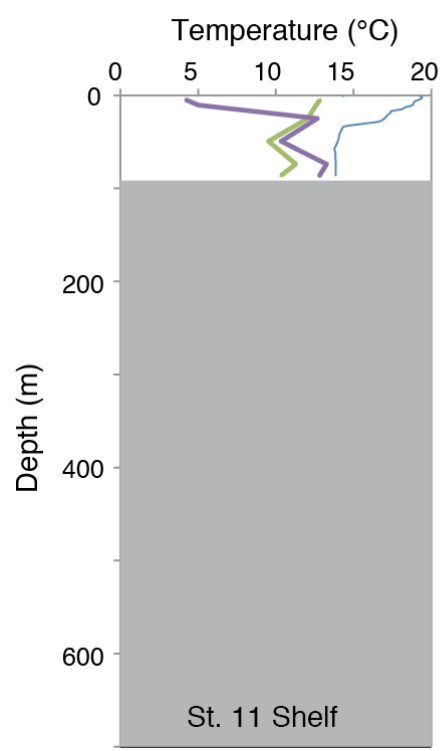

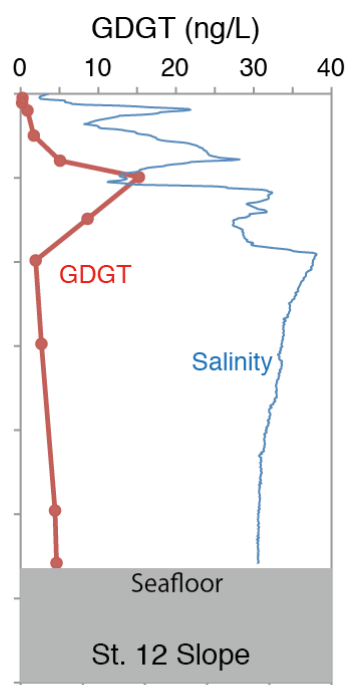

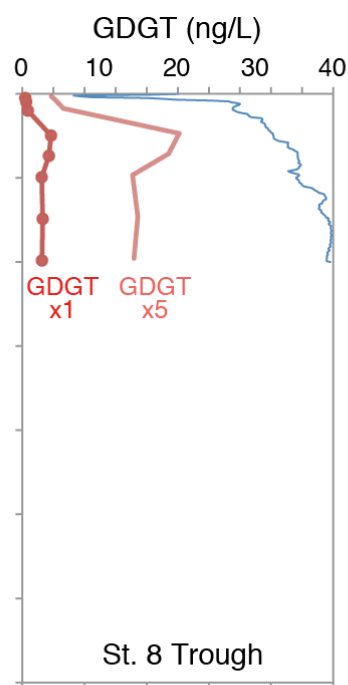

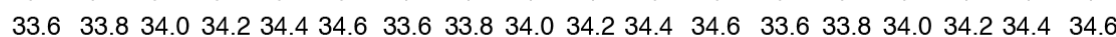
Salinity

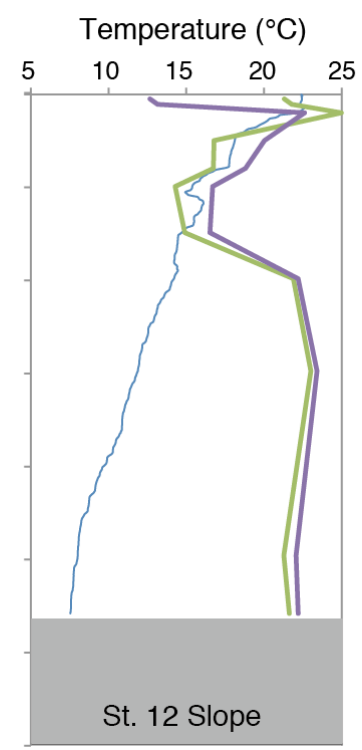

Temperature $\left({ }^{\circ} \mathrm{C}\right)$

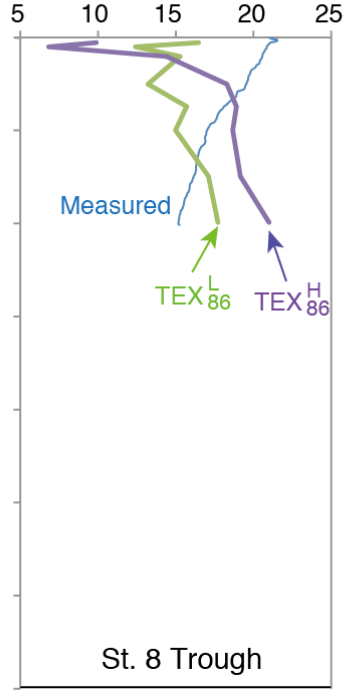

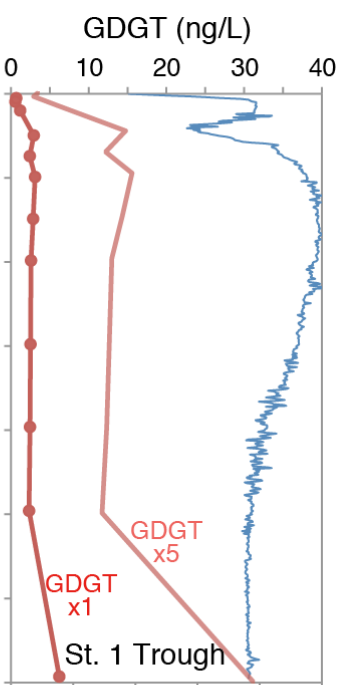

Salinity
Temperature $\left({ }^{\circ} \mathrm{C}\right)$

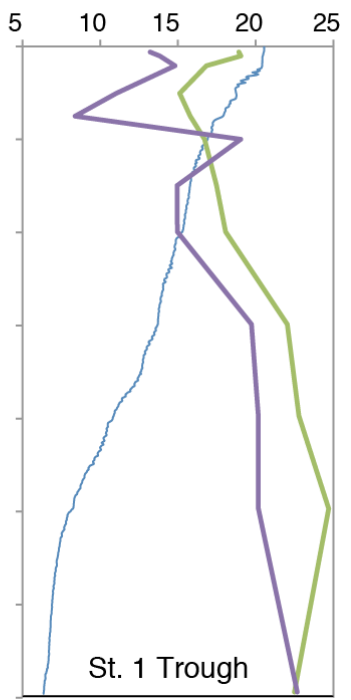

Fig. 3 